\title{
Quantification and control of runoff and soil erosion on avocado orchards on ridges along steep-hillslopes
}

\author{
Cristian Youlton, Paulina Espejo, Jaime Biggs, Marcela Norambuena, \\ Marco Cisternas, Alexander Neaman, and Eduardo Salgado \\ Facultad de Agronomía, Pontificia Universidad Católica de Valparaíso, Casilla 4-D, Quillota, Chile.
}

\begin{abstract}
C. Youlton, P. Espejo, J. Biggs, M. Norambuena, M. Cisternas, A. Neaman, and E. Salgado, 2010. Quantification and control of runoff and soil erosion on avocado orchards on ridges along steep-hillslopes. Cien. Inv. Agr. 37(3): 113-123. Soil erosion increases after building downward ridges along steep hillslopes, in particular during the first winter. This erosion decreases when trees grow, but runoff increases. This study presents results of erosion under five different treatments: (i) soil cover with native vegetation, (ii) bare downward ridges, (iii) downward ridges with six year-old avocado orchard, (iv) downward ridges with plant cover and (v) downward ridges covered with agroindustrial waste sludge. The results revealed $20 \mathrm{t}$ $\mathrm{ha}^{-1}$ of soil erosion during the first year after ridges were built, while mitigation measures can reduce erosion in $90 \%$. Adult orchard showed the largest runoff, which probably is due to the effect of a high and about constant soil moisture during irrigation period and smaller infiltration capacity of eroded soil.
\end{abstract}

Key words: Soil erosion, runoff, agroindustrial waste sludge, plant cover, ridges along slope, steep hillslope, avocado orchards, Chile.

\section{Introduction}

The Region of Valparaíso (Chile) concentrates the largest national surface of avocados (Persea americana Mill.), where an important fraction is cultivated in hillslopes. According to the last Fruit Register, the region has 22.000 hectares of avocados, which is equivalent to $65 \%$ of the total national avocado surface (CIREN-ODEPA, 2008). The expansion of this crop in recent decades was on hillslopes, considered marginal for agriculture in the past (Universidad de Chile, 2005). In the region, there are currently 14,000

Received: November 5, 2009. Accepted: February 9, 2010. Corresponding author: cristian.youlton@ucv.cl hectares cultivated with fruit trees in hillslopes steeper than $8 \%$, mainly with avocados, followed by vineyards and citrus fruits (CIREN, 2007).

A common practice for avocados cultivation in hillslopes is the use of downward ridges. They are built with heavy machinery scraping the soil and accruing longitudinally over the hillside (Figure 1a). Therefore, a deeper stand for plants and more soil aeration is provided together with rapid water drainage through the middle depression between the ridges (Hofshi, 2002). Ridges are normally built 6 meters apart each other, 1 meter high, 2 meter wide at the base, and 0.6 meters on top (Hofshi, 2002). Ridges are segmented every 50 meters with roads in the contour curve (Gardiazabal, 1998). 


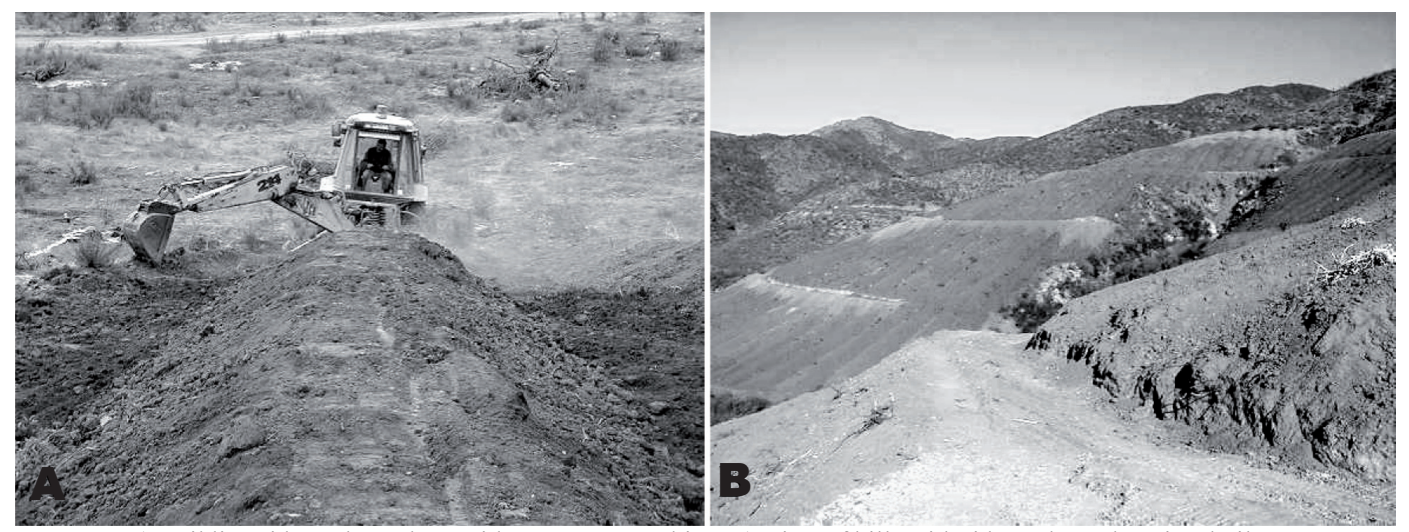

Figure 1. A) Building ridges along slope with excavator machine. B) View of hills with ridges along slope just builts.

Cultivation of fruit trees on downward ridges increases the soil vulnerability to erosion. The soil movement necessary for ridge construction is an erosion process itself, as it provokes a significant movement and alteration of the cropping soil layer (Van Oost et al., 2006). Subsequently, the bare and disaggregated soil (Figure 1b) is exposed to water and eolic erosion, which occurs in three stages: (i) disaggregation and suspension of the individual particles, (ii) particles transport by runoff, and (iii) particles deposition in low zones (Morgan, 1997; Toy et al., 2002). Thus, the disaggregated soil after ridge construction is the first stage of the erosive process.

The loss of soil depends on multiple factors, whose main variables are identified and used in empirical models like USLE (Hudson, 1997). According to Wischmeier and Smith (1978), they are: (i) rainfall (amount, intensity, duration and energy), (ii) soil type (texture, organic matter, structure and permeability), (iii) crop (cover according to the phenological stage and agricultural management like irrigation and pruning), (iv) slope (angle and longitude of the steep angle) and (v) soil conservation practices (use of covers, contour curves, etc.).

The effect of all the variables influencing soil loss is strengthened with downward ridges. The rainfall in the region is concentrated in a few events and it is strongly influenced by the phenomenon of El Niño (Rutllant, 2004; Falvey and Garreaud, 2007). The hillsides used are concentrated in the range of 15 to
$30 \%$ of slope, although there are some orchards planted in steeper slopes higher than $60 \%$ (CIREN, 2007). These soils, mostly clay and clay-loam textured with slow permeability, present a slightly cohesive substrate of meteorized rock which promotes the runoff (Universidad de Chile, 2005). Tree pruning and weed control are carried out in the orchards exposing the bare soil of the middle depressions between ridges. Measures of soil conservation are not normally implemented; on the contrary, as the runoff takes place in the middle of depressions between ridges, the erosive process is promoted.

Erosion causes adverse effects on the orchard (insitu), as well as in faraway sectors (ex-situ). In the first case, there are: a reduction of the effective soil depth for the plant stand, loss of nutrients and organic matter, reduction infiltration velocity and the available soil humidity as well (Lal, 1998, 2001; Toy et al., 2002). Additionally, agricultural practices like more frequent irrigations and fertilizations must be applied to overcome the degradative process which increases the production costs (Ellies, 2000; Toy et al., 2002). Exsitu damage can be produced by a reduction of water quality in the natural courses and irrigation channels, deposition of sediments, diffuse contamination by agrochemicals, soil crusting by deposition of fine sediments and damage to the infrastructure (Peralta, 1976; Morgan, 1997; Lal, 1998; Ellies, 2000).

Erosion in downward ridges would be maximum on bare soil that, nevertheless, might be 
reduced by vegetal cover or soil amendments. A previous research has shown that, in general, the condition of higher loss of soils corresponds to bare soil, while erosion is mitigated through the use of vegetal covers protecting the soil from the impact of rain drops, decreasing the runoff (Albaladejo et al., 2000; Faucette et al., 2006; Francia et al., 2006; Martínez et al., 2006; Zuazo et al., 2008). In regard to the tree soil protection effect, Durán and Rodríguez (2008) indicated that it depends on the percentage of the soil coverage, the modification caused by the foliage in the distribution pattern of drops falling on the soil surface, and the soil coverage by leaf litter under the trees. Experiments made in olive trees in Southern Spain have shown decreased erosion after the fruit trees were grown; however, that reduction is lower when soil is bare without leaf litter under the trees (Gómez et al., 2009). Another strategy used for diminishing erosion is to increase soil aggregation, adding organic matter (Ramos and MartínezCasanovas, 2006; Tejada and González, 2008; Tejada et al., 2009), polyacrylamide (Flanagan et al., 2003) or calcareous salts (Andry et al., 2007; Norton, 2008). Therefore, it is expected that the bare ridges present the higher sediment yield and runoff rate, but reduced along the trees growth and subsequent soil surface coverage. Besides, this process might be mitigated using vegetal coverage and organic or mineral amendments.

Therefore, in this research we evaluated the effect of built ridges with different soil surface coverage or soil amendments compared to native vegetation, on their sediment yield and runoff rates.

\section{Materials and methods}

Area of study

The study was carried out in the area of Quillota city, Region of Valparaíso, Chile. The experimental units were located in the sectors of San Pedro (33 $57^{\prime} \mathrm{S}$; $\left.71^{\circ} 14^{\prime} \mathrm{W}\right)$ and La Palma (32 $53^{\prime} \mathrm{S}$; $71^{\circ} 12^{\prime} \mathrm{W}$ ) (Figure 2), $10 \mathrm{~km}$ apart each other. Both hillsides are northward oriented, $30 \%$ of slope and excluded from grazing. The soils are Alfisols (USDA, 1999), sandy clay loam in the surface and clay in the subsoil (CIREN, 1997). Climate is Mediterranean type, with winter rainfall of torrential type from May to August (Gastó et al., 1987). The mean annual rain is $450 \mathrm{~mm}$, with an annual water deficit of $950 \mathrm{~mm}$ (Santibañez and Uribe, 1990).

\section{Field test}

To evaluate soils loss, 28 x 6 meter runoff plots were installed (Figure 3). The storage system allows collecting after each rainfall event a known fraction of sediments and runoff (Da Veiga and Do Prado, 1993). Subsequently, the dry weight of sediments and the total volume of runoff were determined. A rainfall gauge with data logger was installed in each experimental area, programmed to take readings every 0.2 $\mathrm{mm}$ of rain. The maximum intensity and the kinetic energy in 30 minutes $\left(\mathrm{I}_{30}\right)$ were determined for each rainfall (Almorox et al., 1994).

\section{Treatments}

San Pedro experimental site. Two runoff plots were installed on the same hillside in the experimental site of San Pedro during the fall of 2004 and a third plot, in 2006. The measurement of the erosion and runoff allowed comparing two and then three types of soil cover. A control plot corresponded to native vegetation with $54 \%$ of acacia bushes (Acacia caven Moll.), tebo (Trevoa trinerva Miers.) and $100 \%$ of cover with annual plant type. The second plot had bare ridges recently built along the hillslope. A third ridge plot was added (2006) on the same hillside, covered with avocados cv. Hass. The avocado trees were planted in 2001, in a $6 \mathrm{~m} \mathrm{x} 3$ $\mathrm{m}$ frame, maintained through pruning between 3 to $4 \mathrm{~m}$ high and wide approximately, and irrigated with $24 \mathrm{~L} \mathrm{H}^{-1}$ microsprinklers. Weeds were controlled with post-emergency herbicide in both ridge types, bare and avocado covered. Data corresponding to 5 years measurements are available for this experimental site. 

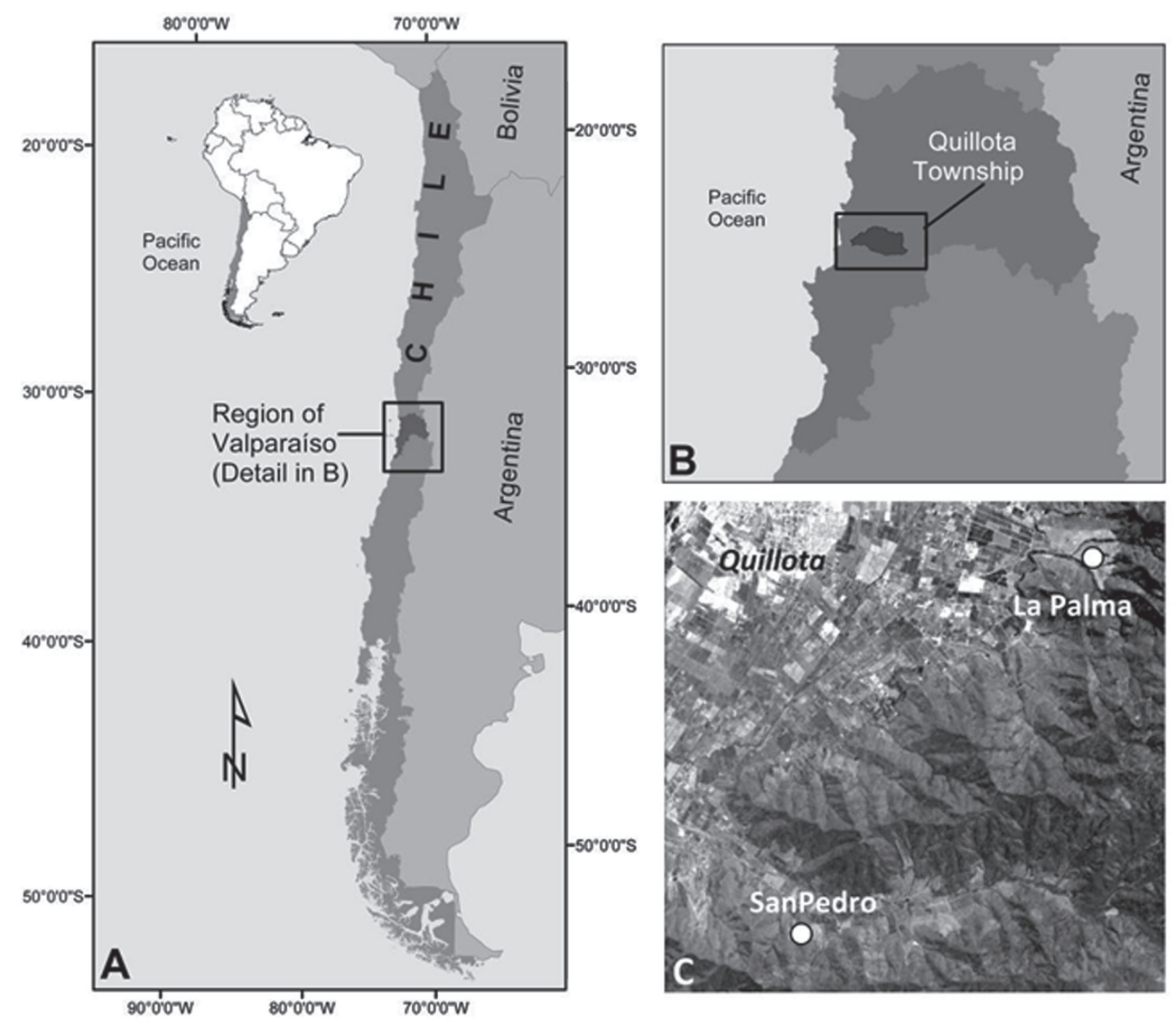

Figure 2. A) Localization of Chile in SouthAmerica. B) Localization of Quillota Township in Region of Valparaiso, Chile. C) Localization of experimental areas (San Pedro and La Palma) in County of Quillota. Distance between experimental areas is $10 \mathrm{~km}$.

La Palma experimental site. Three runoff plots were installed in 2006. Soil was prepared by scraping between the ridges built the previous year. Three treatments were applied: (i) application of $60 \mathrm{tha}^{-1}$ of agroindustrial sludge from tomato paste production, including surface in the middle depression between the ridges, free of weeds with post-emergency herbicide, (ii) a vegetal cover was established in the middle depression between the ridges, sowing a mixture of Lolium multiflorum Lam., var. Wimera (23 $\left.\mathrm{kg} \mathrm{ha}^{-1}\right)$, Medicago polymorpha L. $\left(24 \mathrm{~kg} \mathrm{ha}^{-1}\right)$, Falaris sp. $\left(17 \mathrm{~kg} \mathrm{ha}^{-1}\right)$, Trifolium subterraneum L., var. Campeda $\left(10 \mathrm{~kg} \mathrm{ha}^{-1}\right)$ and var. Gosse (10 $\left.\mathrm{kg} \mathrm{ha}^{-1}\right)$. This plot was initially fertilized with urea in the middle depression between the ridges during fall (238 $\left.\mathrm{kg} \mathrm{ha}^{-1}\right)$, triple superphosphate $\left(238 \mathrm{~kg} \mathrm{ha}^{-1}\right)$, elemental sulphur $(60 \mathrm{~kg}$ $\mathrm{ha}^{-1}$ ) and Borax (23 $\left.\mathrm{kg} \mathrm{ha}^{-1}\right)$, (iii) ridge with bare soil, maintained free of weeds by applications of post-emergency herbicides. Data corresponding to 3 years measurements are available for this experimental site.

\section{Experimental analysis}

Due to the interannual variability of rainfall regime in the area, a two way design was used, considering the years as treatments replications. To determine significant differences for runoff and erosion among treatments, analysis of variances and Tukey multiple comparison tests ( $\mathrm{p} \leq$ 0.05 ) were performed.

To evaluate the incidence of rainfall from each erosive rain event (rain higher than $13 \mathrm{~mm}$, according to Wischmeier and Smith, 1978) an analysis of correlation between runoff rate and sediment yield was done for each treatment (Minitab 15, Minitab Inc., Pennsylvania, U.S.A., 2008). 


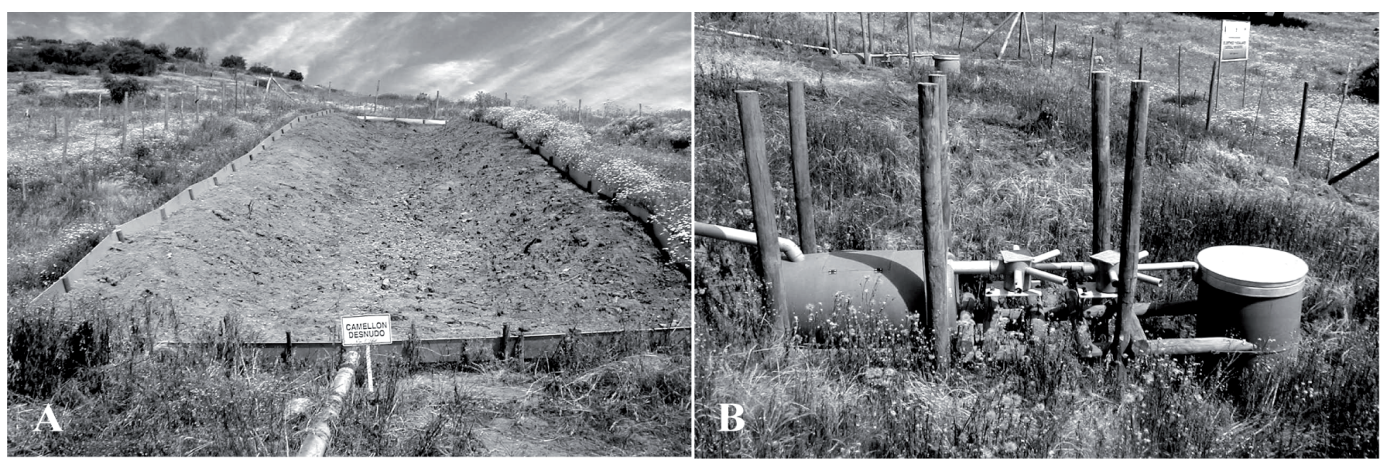

Figure 3. A) Bounded plot used for collet soil erosion and runoff. In its lower limit has a channel that carries water and sediment into the tank system (B).

\section{Results}

\section{Annual rainfall regime}

Total annual rainfall presented high interannual variability (Figures $4 \mathrm{a}$ and $4 \mathrm{~b}$ ). Comparing total annual rainfall against annual erosive rain, it is observed that most of the rain events are potentially erosive. The highest rain event of each year represents between 20 and $30 \%$ of the annual rain and also between 30 to $70 \%$ of the erosive rain events.

Comparing the rainfall regimes between the experimental sites, it was found that San Pedro presents a more extreme behaviour than La Palma. In years of high rainfall, San Pedro shows higher amounts, while in years with scarce rain, La Palma gets the most. The average maximum intensity

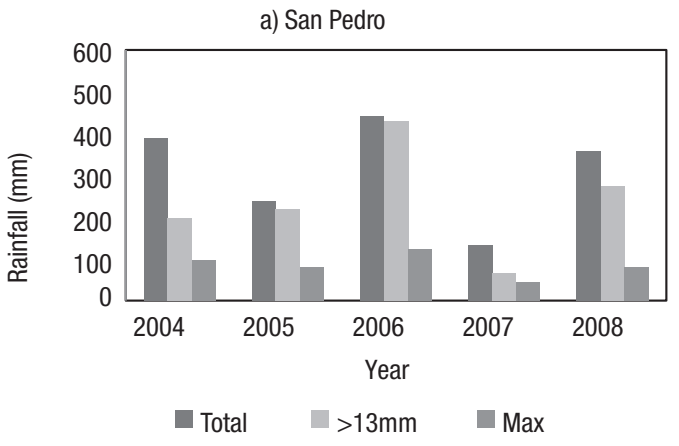

in 30 minutes $\left(\mathrm{I}_{30}\right)$ from both sectors are very simi$\operatorname{lar}\left(7.6 \mathrm{~mm} \mathrm{H}^{-1}\right)$, although the maximum observed value in San Pedro is slightly higher than in $\mathrm{La}$ Palma (22 and $19 \mathrm{~mm} \mathrm{H}^{-1}$, respectively). In regard to the kinetic energy, it is observed that San Pedro presents an average value slightly higher than $\mathrm{La}$ Palma (9 and $7 \mathrm{MJ} \mathrm{ha}^{-1}$, respectively), a relation that is maintained when the maximum values are compared (27 and $17 \mathrm{MJ} \mathrm{ha}^{-1}$, respectively).

\section{Runoff}

In the area of San Pedro, with three soil cover conditions, the higher runoff was found in the ridges with avocado trees, followed by ridges with bare soil. The minimum occurred in the condition with native vegetation (Figure 5a). Significant differences $(\mathrm{p} \leq 0.05)$ were found

Figure 4. Anual rainfall in experimental areas. (Total: sum of anual rainfall; $>13 \mathrm{~mm}$ : sum of anual erosive rainfall events; Max: highest rainfall event on the year).

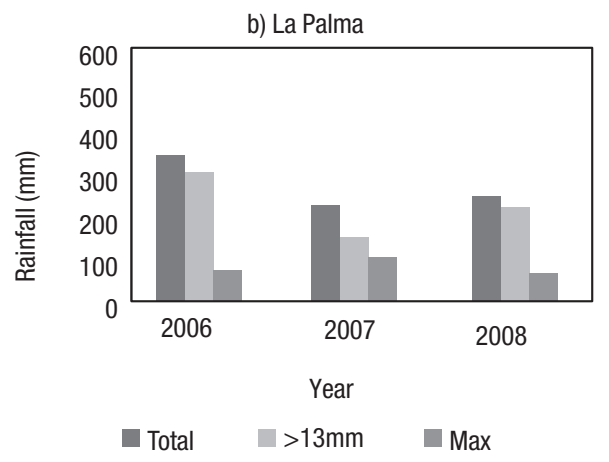


Table 1. Anual mean runoff by treatment and experimental area. Results are not comparables between experimental areas. $(\mathrm{p} \leq 0.05$. $* \mathrm{n}=5 ; * * \mathrm{n}=3)$.

\begin{tabular}{lcllc}
\hline \multicolumn{2}{c}{ a) San Pedro } & & \multicolumn{2}{c}{ b) La Palma } \\
\cline { 1 - 2 } \cline { 5 - 5 } Treatment & Mean Runoff $(\mathrm{mm})$ & & Treatment & Mean Runoff (mm) \\
\hline Natural vegetation & $2.5^{*} \mathrm{a}$ & & Bare soil & $41^{* * a} \mathrm{a}$ \\
Bare soil & $14^{*} \mathrm{ab}$ & & Plant cover & $33^{* *} \mathrm{a}$ \\
Avocado orchard & $52^{* *} \mathrm{~b}$ & & Sludge & $27^{* *} \mathrm{a}$ \\
\hline
\end{tabular}
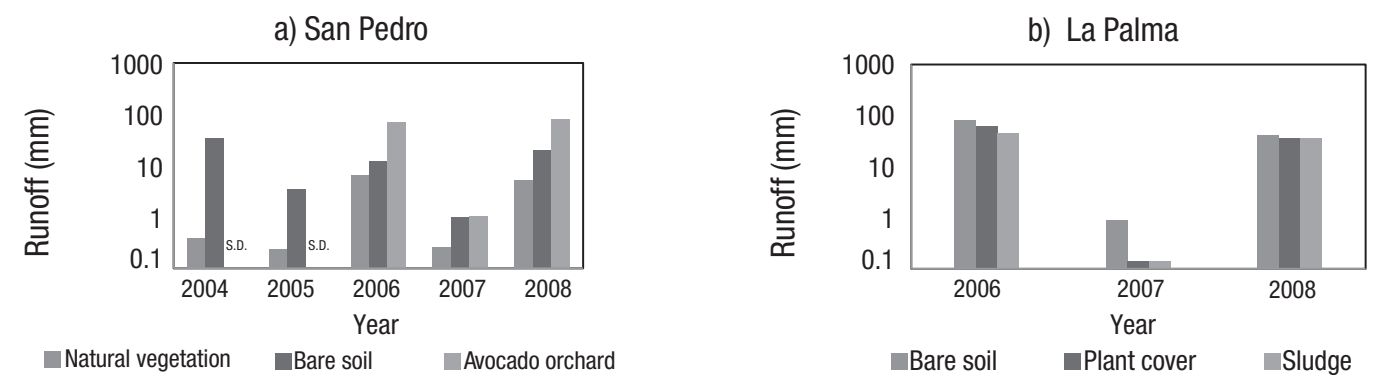

Figure 5. Anual runoff in experimental areas, data in $\mathrm{mm}$. Vertical axis in logarithmic scale. W.D.: without data for bare soil in years 2004 and 2005.

only between native vegetation and ridges with avocado trees (Table 1a).

Regardless of the apparent runoff reduction caused by the soil amendment in La Palma, there was not a significant difference in comparison with the other treatments (Figure $5 \mathrm{~b}$ and Table 1b). This fact is more visible in 2007, a year of low rainfall. The apparent effect corresponds to the logarithmic scale used, as the values recorded are extremely low and similar between each other $(0.9,0.14$, and $0.14 \mathrm{~mm})$, with respect to the years of high rainfall.

In general terms, the annual runoff is highly dependent of the rainfall regime. Years of high rainfall (2004, 2006 and 2008) produced higher runoff in all treatments, in particular in sector $\mathrm{La}$ Palma (Figure 5a and 5b). This relation is significant $(\mathrm{p} \leq 0.05)$ during the whole period of study (Table $2 \mathrm{a}$ and $2 \mathrm{~b}$ ), but highly determinant for the

Table 2. Correlation between rainfall and runoff/soil erosion; and between runoff and soil erosion. ( $\mathrm{p} \geq 0.05 ; \mathrm{n}$ : erosive rain events; RF: rainfall; RN: runoff; ER: erosión; ns: not significant).

\begin{tabular}{lcccc}
\hline $\begin{array}{l}\text { a) San Pedro } \\
\text { Treatment }\end{array}$ & $\mathrm{n}$ & RF-RN & RF-ER & RN-ER \\
\hline Natural vegetation & 25 & 0.44 & $\mathrm{~ns}$ & $\mathrm{~ns}$ \\
Bare soil & 25 & 0.51 & $\mathrm{~ns}$ & 0.92 \\
Avocado orchard & 16 & 0.81 & 0.66 & $\mathrm{~ns}$ \\
\hline b) La Palma & $\mathrm{n}$ & $\mathrm{RF}-\mathrm{RN}$ & $\mathrm{RF}-\mathrm{ER}$ & $\mathrm{RN}-\mathrm{ER}$ \\
Treatment & 18 & 0.53 & $\mathrm{~ns}$ & 0.75 \\
Bare soil & 18 & 0.52 & $\mathrm{~ns}$ & 0.57 \\
Plant cover & 18 & 0.48 & 0.52 & 0.66 \\
Sludge & & & &
\end{tabular}


treatment of ridges with avocado $(\mathrm{r}=0.81)$ in San Pedro.

\section{Erosion}

Soil erosion presents an interannual variability depending on the rainfall regime. In years of heavy rain (2004, 2006 and 2008), the values of erosion are higher in both sectors (Figure 6a and $6 b)$. This determines the erosion $(p \leq 0.05$; Table $2 \mathrm{a}$ and $2 \mathrm{~b}$ ) in all treatments with ridges, but the highest relationship occurs in bare ridges $(r=0.92$ and 0.75$)$ in San Pedro and $\mathrm{La}$ Palma, respectively. The exception is represented by ridges with avocado and native vegetation in San Pedro.

In San Pedro, the highest erosion was recorded in bare ridge (Figure 6a). This was in particular intense during the first year $\left(20 \mathrm{tha}^{-1}\right)$, while in further years the effect decreases drastically $(<$ $\left.2 \mathrm{tha}^{-1}\right)$. This may be due to the higher vulnerability of the ridge just built, as it presents a highly disaggregated soil, and coincidentally, it corresponds to a year of high rainfall. The opposite situation is present in the treatment with native vegetation, which annual values are extremely low $\left(<0.04 \mathrm{t} \mathrm{ha}^{-1}\right)$ and homogenous. A similar situation occurs in the condition of avocado orchard, with low levels of erosion $\left(<0.8 \mathrm{t} \mathrm{ha}^{-1}\right)$ and small variation. Regardless of the high erosion of the bare ridge during the first year (Figure 6a and 6b), it is not possible to determine statistical differences with the other treatments (Table 3a).

In La Palma, the treatment presenting higher erosion is bare ridge (Figure 6b) as well. Like in San Pedro the highest loss of soil occurred during the first year $\left(22 \mathrm{t} \mathrm{ha}^{-1}\right)$. This situation decreased $\left(<9 \mathrm{t} \mathrm{ha}^{-1}\right)$ in further years, following the same tendency observed in San Pedro. Finally, soil amendments (vegetal cover and agroindustrial waste sludge) significantly decreased $(\mathrm{p} \leq 0.05)$ the sediment yield, approximately by $90 \%$ with respect to the bare ridge condition (Table 3b).

Table 3. Anual mean soil erosion by treatment and experimental area. Results are not comparables between experimental areas. $\left(\mathrm{p} \leq 0.05 .{ }^{*} \mathrm{n}=5 ; * * \mathrm{n}=3\right)$.

\begin{tabular}{llll}
\hline a) San Pedro & & b) La Palma & \\
\hline Treatment & $\begin{array}{c}\text { Mean soil erosion } \\
\left(\mathrm{t} \mathrm{ha}^{-1} \mathrm{year}^{-1}\right)\end{array}$ & Treatment & $\begin{array}{c}\text { Mean soil erosion } \\
\left(\mathrm{t} \mathrm{ha}^{-1} \mathrm{year}^{-1}\right)\end{array}$ \\
\hline Natural vegetation & $0.03 * \mathrm{a}$ & Bare soil & $10^{* * \mathrm{a}}$ \\
Bare soil & $4.5 * \mathrm{a}$ & Plant cover & $0.7 * \mathrm{f}^{*} \mathrm{~b}$ \\
Avocado orchard & $0.5 * * \mathrm{a}$ & Sludge & $0.2^{* * \mathrm{~b}}$ \\
\hline
\end{tabular}
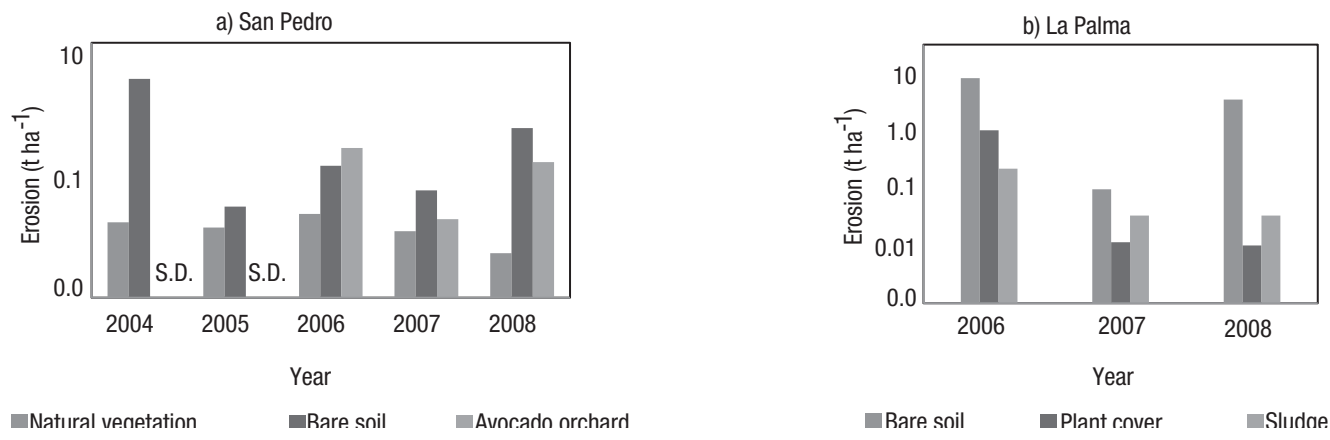

Figure 6. Anual soil erosion in experimental areas, data in $\mathrm{t} \mathrm{ha}^{-1}$. Vertical axis in logarithmic scale. W.D.: without data for bare soil in years 2004 and 2005. 


\section{Discussion}

The rainfall showed high variability during the study, with years of high and low rainfall annual totals. This behaviour is normal in Central Chile due to the strong influence of the South Oscillation, causing El Niño and La Niña events (CONAMA, 2006). Because of this, and in particular during years of El Niño, a large amount of rainfall is concentrated in a few torrential events (Rutllant, 2004). The differences recorded between San Pedro and La Palma may be attributed exclusively to the relief of the land. San Pedro is a narrow sub basin with boxing-in borders that prevent the entrance of weak meteorological fronts. La Palma, on the other hand, is located in the middle of an open valley. This difference was observed in some events where rainfall occurred only in La Palma.

The increment of runoff is equivalent to a reduction of water infiltrated into the soil, which modifies the natural water balance in the microbasin. This varies according to the different conditions and stages of the soil coverage, with maximum values in ridges with avocado (in average 20 times higher than the native vegetation). A possible cause could be the effect from irrigation keeping the ridge soils with high humidity. This might promote their early saturation and subsequent runoff in each rain event (Hino et al., 1988). Other possible causes of this high runoff are: (1) the old age of the ridges with avocado trees, which after 5 years of erosion process have exposed deep soil horizons with less infiltration rates (Peralta, 1976; Lal, 1998); (2) the surface crusting due to the pore sealing with fine eroded sediments (Durán and Rodríguez, 2008) and, (3) the compaction provoked by the workers stepping the humid soil. Due to the aforementioned, this is the only treatment presenting a clear statistical relation between the rainfall and the runoff.

The minimum runoff occurs in the condition of native vegetation. It corresponds to an undisturbed soil, maintaining the natural structure and porosity, protected by the bush-like plant cover and with an organic litter layer on the surface. These factors enable the water infiltration and decrease the runoff (Rodríguez et al., 2000; Durán and Rodrí- guez, 2008). An intermediate situation occurs in bare ridge, where the results are not statistically different from the other treatments as they present intermediate values with high variability. This behaviour is maintained even with the exclusion of the high values from the first year of study.

The first winter after the ridge construction is the most vulnerable moment to erosion, losing approximately $20 \mathrm{t} \mathrm{ha}^{-1}$. This situation is common for San Pedro and La Palma, due to the exposition of disaggregated surface soil, which is rapidly drifted by the runoff. This is supported by correlation analysis, which shows that this is the only treatment where the erosion is strongly conditioned by the runoff. In subsequent years, these values decrease, possibly by the soil reaggregation or the lesser availability of erodible particles on soil surface (Ollesch and Vacca, 2002). This reduction is higher in San Pedro, possibly due to slight differences of soils, age of ridges or variation of rainfall between the two places.

The high runoff recorded in ridges with avocado trees does not represent large erosion. This may be due to the questionable protecting effect from the trees covering the soil. Durán and Rodríguez (2008) indicate that the tree protection depends on the cover percentage, on the modification of the size of the drops falling from the foliage, and on the litter cover under the trees. In young avocado orchards, it is possible to observe a small litter cover, which accumulates in the lower part of the middle depression between the ridges, by effect of runoff and gravity. This effect is more noticeable because the absence of a herbaceous layer under the trees due to constant applications of herbicides. Finally, the lower erosion may be due to a lower availability of erodible particles. Likewise, Ollesch and Vacca (2002) report diminished erosion after 5 years by a reduction of available particles for transport.

The soil amendment strategies reduce erosion, but not runoff. This might be due to the downward design of ridges for rapid evacuation of the rain waters. Due to the form of the ridge, the runoff is concentrated in the depression between them. However, regardless of the high runoff, the plant cover and the agroindustrial waste sludge 
succeed on retaining the soil, reducing the erosion by $90 \%$. The grass provides a protection to the soil against the impact from rain drops, while the roots provide a filamentous matrix retaining the soil and providing organic matter and therefore improving the stability of soil aggregates (Casermeiro et al., 2004; Durán and Rodríguez, 2008). In the case of the application of agroindustrial waste sludge, the organic matter would agglomerate and agglutinate the soil particles, conferring resistance to the soil against the impact of the rain drops (Ojeda et al., 2003; Ros et al., 2003; Henríquez, 2005). Another possible secondary effect might be the reduction of the erodible area after the inclusion of the agroindustrial waste sludge in the first centimetres of soil, leaving a non-quantified fraction of organic matter exposed on the surface.

To measure the level of erosion, it is possible to use the concept of soil erosion tolerance, which is a theoretical value equivalent to its formation rate. In fragile conditions, as in the cases of surface soils or highly erodible ridges, it is recommendable that the annual erosion does not exceed $2 \mathrm{t} \mathrm{ha}^{-1}$ year $^{-1}$ (Morgan, 1997; Toy et al., 2002). Therefore, it is possible to state that the loss of soils in ridges is high and critical during the first rainy period $\left(20 \mathrm{t} \mathrm{ha}^{-1}\right)$, which may be reduced to a tolerable level by either the establishment of plant coverage or applying agroindustrial waste sludge.

Finally, the results presented in this work were collected in plots which were half the size of commercial orchards $(50 \mathrm{~m})$ and without replications. Therefore, they do not represent necessarily what occurs in orchards under commercial management neither they have statistical precision. Joel et al. (2002) determined experimentally in Central Chile that the relative runoff depended in a large extent on the length evaluated. Thus, runoff plots of $10 \mathrm{~m}$ of length showed $40 \%$ of the erosion registered in $0.5 \mathrm{~m}$ runoff plots.

\section{Acknowledgements}

Research financed by the project DI 242711/04 of Pontificia Universidad Católica de Valparaíso during 2004 and 2005, and by Servicio Agrícola y Ganadero between 2006 and 2009. The experimental area of San Pedro was provided by Mr. Luis León, while the sector La Palma was provided by Inversiones Quintil S.A.

\section{Resumen}

C. Youlton, P. Espejo, J. Biggs, M. Norambuena, M. Cisternas, A. Neaman y E. Salgado. 2010. Cuantificación y control de la escorrentía y erosión en huertos de paltos, cultivados en camellones a favor de pendientes escarpadas. Cien. Inv. Agr. 37(3): 113-123. La erosión de suelos en un huerto de paltos cultivados en camellones a favor de pendiente es alta en la condición de camellón desnudo, especialmente durante el primer invierno. Luego, la pérdida de suelo disminuye con el desarrollo de los árboles, ocurriendo lo contrario con la escorrentía. Esta práctica, masificada en Chile central durante las últimas décadas, deja el suelo descubierto y disgregado, favoreciendo la erosión y escorrentía. En el presente trabajo se cuantifica el transporte de sedimentos durante al menos tres años bajo tres cubiertas diferentes: i) antes de la preparación de suelo, con vegetación nativa, ii) camellón desnudo y iii) camellón con paltos adultos. De igual forma, se evalúan medidas de mitigación como i) camellón con cobertura herbácea y ii) camellón con lodos de agroindustria. Los resultados muestran una pérdida de más de $20 \mathrm{t} \mathrm{ha}^{-1}$ de suelo durante el primer invierno tras el establecimiento de camellones, en tanto que las medidas de mitigación reducen la erosión un 90\%. La mayor escorrentía registrada en el huerto se debe, probablemente, al efecto del riego y la menor infiltración de un suelo ya erosionado.

Palabras clave: Erosión, escorrentía, camellones, lodos, cobertura herbácea, paltos en laderas, Chile. 


\section{References}

Albaladejo Montoro, J., J. Alvarez Rogel, J. Querejeta, E. Díaz, and V. Castillo. 2000. Three hydroseeding revegetation techniques for soil erosion control on anthropic steep slopes. Land Degradation \& Development 11:315-325.

Almorox, A. J., R. De Antonio, A. Saa, M. Cruz, and J.M. Gasco. 1994. Métodos de estimación de la erosión hídrica. Editorial Agrícola Española. Madrid, España. 150 pp.

Andry, H., T. Yamamoto, and M. Inoue. 2007. Effectiveness of hydrated lime and artificial zeolite amendments and sedum (Sedum sediforme) plant cover in controlling soil erosion from an acid soil. Australian Journal of Soil Research 45:266279.

Casermeiro, M. A., J. A. Molina, M. T. de La Cruz Caravaca, J. Hernando Costa, M.I. Hernando Massanet, and P.S. Moreno. 2004. Influence of scrubs on runoff and sediment loss in soils of Mediterranean climate. Catena 57:91-107.

CIREN. 1997. Estudio agrológico. V región. Tomo 1, Publicación 116. Centro de Información de Recursos Naturales. Santiago, Chile. 180 pp.

CIREN. 2007. Determinación y evaluación de la fragilidad de laderas en la cuenca de Casablanca y en las cuencas hidrográficas de los ríos Petorca, La Ligua y Aconcagua, V Región. Centro de Información de Recursos Naturales. Santiago, Chile. 73 pp.

CIREN-ODEPA. 2008. Principales resultados del catastro frutícola. Región de Valparaíso. Oficina de Estudios y Políticas Agrarias, Ministerio de Agricultura, Gobierno de Chile. Centro de Información de Recursos Naturales. Santiago, Chile. 21 pp.

CONAMA. 2006. Estudio de la variabilidad climática en Chile para el siglo XXI. Comisión Nacional del Medio Ambiente. Santiago, Chile. 63 pp.

Da Veiga, M., and W. Do Prado. 1993. Manual para la instalación y conducción de experimentos de pérdida de suelos. FAO. Santiago, Chile. 34 pp.

Durán Zuazo, V., and C. Rodríguez Pleguezuelo. 2008. Soil erosion and runoff prevention by plant covers. A review. Agronomy for Sustainable Development 28:65-86.

Ellies, A. 2000. Soil erosion and its control in ChileAn overview. Acta Geologica Hispanica 35:279284.

Falvey M., and R. Garreaud. 2007. Wintertime precipitation episodes in Central Chile: associated meteorological conditions and orographic influences. Journal of Hydrometeorology 8:171-193.

Faucette, L.B., L.M. Risse, C.F. Jordan, M.L. Cabrera, D.C. Coleman, and L.T. West. 2006. Vegetation and soil quality effects from hydroseed and compost blankets used for erosion control in construction activities. Journal of Soil and Water Conservation 61:355-362.

Flanagan, D.C., L. D. Norton, J.R. Peterson, and K. Chaudhari. 2003. Using polyacrylamide to control erosion on agricultural and disturbed soils in rainfed areas. Journal of Soil and Water Conservation 58:301-311.

Francia Martínez, J.R., V.H. Durán Zuazo, and A. Martínez Raya. 2006. Environmental impact from mountainous olive orchards under different soil management systems (SE Spain). Science of the Total Environment 358:46-60.

Gardiazabal, F. 1998. Factores agronómicos a considerar en la implantación de un huerto de paltos. Sociedad Gardiazabal y Magdhal Ltda. In: Seminario Internacional de Paltos. Viña del Mar, Chile. p. 17-37.

Gastó, J., S. Gallardo, and D. Contreras. 1987. Caracterización de los pastizales de Chile: reinos, dominios y provincias. Pontificia Universidad Católica de Chile. Santiago, Chile. 292 pp.

Gómez, J.A., T.A. Sobrinho, J.V. Giráldez, and E. Fereres. 2009. Soil management effects on runoff, erosion and soil properties in an olive grove of Southern Spain. Soil \& Tillage Research 102:5-13.

Henríquez, O. 2005. Valoración de lodos provenientes de plantas de tratamiento de aguas servidas como mejorador de suelos degradados. In: González, S., F. Tapia, and R. Ruiz, (eds.). Seminario: Uso benéfico de lodos. Proyecto: Valorización de lodos como fertilizantes. Santiago, Chile. p. 63-72.

Hino, M., Y. Odaka, K. Nadaoka, and A. Sato. 1988. Effect of initial soil moisture content on the vertical infiltration process - a guide to the problem of runoff-ratio and loss. Journal of Hydrology 102:267-284.

Hofshi, R. 2002. The Chilean avocado industry: an overview. Avoresearch. 2:1-12

Hudson, N.W. 1997. Medición sobre el terreno de la erosión del suelo y de la escorrentía. Boletín FAO 68. Roma, Italia. 147 pp.

Joel, A., I. Messing, O. Seguel, and M. Casanova. 2002. Measurement of surface water runoff from 
plots of two different sizes. Hydrological Processes 16:1467-1478.

Lal, R. 2001. Soil degradation by erosion. Land Degradation \& Development 12:519-539.

Lal, R. 1998. Soil erosion impact on agronomic productivity and environment quality. Critical Reviews in Plant Sciences 17:319-464.

Martínez Raya, A., V.H. Durán Zuazo, and J.R Francia Martínez. 2006. Soil erosion and runoff response to plant-cover strips on semiarid slopes (SE Spain). Land Degradation \& Development 17:1-11.

Morgan, R.P.C. 1997. Erosión y conservación del suelo. Segunda edición. Madrid, España. Ediciones Mundi Prensa. 343 pp.

Norton, L.D. 2008. Gypsum soil amendment as a management practice in conservation tillage to improve water quality. Journal of Soil and Water Conservation 63:46A-48A.

Ollesch, G.,and A. Vacca. 2002. Influence of time on measurement results of erosion plot studies. Soil \& Tillage Research 67:23-39.

Ojeda, G., J.M. Alcañiz, and O. Ortiz. 2003. Runoff and losses by erosion in soils amended with agroindustrial waste sludge. Land Degradation \& Development 14:563-573.

Peralta, M. 1976. Uso, clasificación y conservación de suelos. Servicio Agrícola y Ganadero. Santiago, Chile. 340 pp.

Ramos, M.C., and J.A. Martínez-Casanovas. 2006. Erosion rates and nutrient losses affected by composted cattle manure application in vineyards soils of NE Spain. Catena 68:177-185.

Rodríguez, N., E. Ruz, P. Valenzuela, and C. Belmar. 2000. Efecto del sistema de laboreo en las pérdidas de suelo por erosión en la rotación trigo-avena y praderas en la precordillera andina de la región centro sur. Agricultura Técnica 60:259-269.

Ros, M., M.T. Hernández, and C. García. 2003. Bioremediation of soil degraded by seawage sludge: effects on soil properties and erosion losses. Environmental Management 31:741-747.

Rutllant, J. 2004. Aspectos de la circulación atmosférica de gran escala asociada al ciclo ENOS
1997-1999 y sus consecuencias en el régimen de precipitación en Chile central. S. Avaria, S., J. Carrasco, J. Rutllant and E. Yáñez. (eds.). El Niño-La Niña 1997-2000. Sus efectos en Chile. CONA. Valparaíso, Chile. p. 61-76.

Santibáñez, F., and J. Uribe. 1990. Atlas agroclimático de Chile: regiones V y Metropolitana. Universidad de Chile. Santiago, Chile. 65 pp.

Tejada, M., and J.L. González. 2008. Influence of two organic amendments on the soil physical properties, soil losses, sediments and runoff water quality. Geoderma 145:352-334.

Tejada, M., A.M. García-Martínez, and J. Parrado. 2009. Effects of a vermicompost composted with beet vinasse on soil properties, soil losses and soil restoration. Catena 77:238-247.

Toy, T., G. Foster, and K. Rernard. 2002. Soil erosion: processes, prediction, measurement and control. New York, U.S., John Wiley \& Sons. 338 pp.

Universidad de Chile. 2005. Estado del medio ambiente en Chile 2005. Segunda edición. Centro de Análisis de Políticas Públicas. 371 pp.

United States Department of Agriculture (USDA). 1999. Soil Taxonomy. A Basic System of Soil Classification for Making and Interpreting Soil Surveys. USDA. Washigton DC, USA. $871 \mathrm{pp}$.

Van Oost, K., G. Govers, S. de Alba, and T. A. Quine. 2006. Tillage erosion: a review of controlling factors and implications for soil quality. Progress in Physical Geography 30:443-466.

Wischmeier W.H., and D.D. Smith. 1978. Predicting rainfall erosion losses: A guide to conservation planning, USDA-ARS Agricultural Handbook No. 537. Washington, DC. 58 pp.

Zuazo, V.H.D., C.R.R. Pleguezuelo, J.R.F. Martínez, A.M. Raya, L.A. Panero, B.C. Rodríguez, and M.C.N. Moll. 2008. Benefits of plant strips for sustainable mountain agriculture. Agronomy for Sustainable Development 28:497-505. 
5314 -10 YOULTON 37-3.indd 124 20-12-2010 16:15:14 